\title{
Analysis of Carbon Emission Accounting Practices of Leading Carbon Emitting European Union Companies
}

\author{
By Haseeb Ayaz ${ }^{\dagger}$
}

\begin{abstract}
After the withdrawal of IFRIC 3: Emission Rights in 2005, members of European Union Emissions Trading Scheme (EU ETS) do not have an authoritative course of action for carbon emission allowances accounting. They are allowed to adopt variant accounting approaches to account for granted and purchased carbon emission allowances which has created multiplicity in accounting practices and questions the comparability of different entities in the scheme. By adopting a content analysis methodology, this research scrutinizes accounting approaches followed by the companies in European Union Emission Trading System (EU ETS), and discloses the practices of accounting adopted by these companies to account for carbon permits without the presence of any precise guidelines by the accounting standard setters. This study also highlights the current accounting approaches used for emissions accounting together with providing an ultimate solution in this regard. Because the accounting treatment followed by an entity will produce effects on its financial statements, the results of this research will probably be of high importance to experts of accounting, standard setters, investors, stakeholders, auditors, and academic audiences.
\end{abstract}

Keywords: Carbon Emissions Allowances, Carbon Emissions Accounting, IFRIC 3, IFRS.

\section{Introduction}

Carbon markets expansion has produced a mass of challenges for the corporations - of which, accounting for Carbon Emissions is perhaps the least implicit area. Expert of carbon trading, Europe, is still working on agreement on how to record carbon emission rights in the financial statements whereas, companies emitting carbon emissions in the United States have just started to struggle with the accounting issues of an already multifaceted and unknown market. In addition, as carbon markets grow and integrate new constituents, more and more accounting issues will persist to materialize (Deloitte, 2009).

The emergence of EU Carbon Emission Trading Scheme on $1^{\text {st }}$ January 2005 was one of the most important actions until today to deal with the change in climate. Immediately, it has fashioned a host of challenges and opportunities for the interrelated organizations within the range of the scheme and for overseeing supervisory bodies. The scheme has also shaped a lucid correlation between business value and emissions by injecting the carbon emissions values on to the financial statements. This communicates a comprehensible message

\footnotetext{
${ }^{\dagger} \mathrm{PhD}$ Student, Anglia Ruskin University, UK.
} 
that 'No more free Carbon Emissions are available' (Romic, 2010). The key rationale of an Emissions Trading Scheme is to attain lucrative and efficiently levelheaded decrease in Green House Gas Emissions. On $1^{\text {st }}$ January 2005, Phase I of the EU ETS was inaugurated with the purpose to generate the essential practical infrastructure for carbon trading and to permit the users to achieve understanding about the carbon market mechanism. On $1^{\text {st }}$ January 2008, Phase II of the EU ETS was started in conjunction with Kyoto Protocol pledge taking force, which has ended on $31^{\text {st }}$ December 2012. Finally, Phase III is intended to operate for the period 2013-2020 (Ellerman and Buchner, 2008).

Already, 32 countries are participating within Carbon Emissions Trading Scheme at present, whilst others are approaching on the way to the adoption of such kind of a scheme globally. Among all, EU Carbon Emissions Trading Scheme is the most prominent and the largest scheme in the world. Figures reveals that a sum of 8200 million metric tonnes of carbon rights valued around US\$ 9200 million traded worldwide in 2008, in which EU Carbon Emission Trading Scheme accounted for two-thirds of the global quantity and threequarters of global value. By the involvement of these significant values, accounting for carbon emission allowances by the European Union Companies in their financial statements has also become a question of huge importance (Point Carbon, 2010).

The need to correspond evidently and explicitly to stakeholders about the consequences of carbon emissions on the performance of the companies due to the emergence and development of carbon markets in Europe and other continents of the world has attained huge significance (Romic, 2010).

Nations at present are following dissimilar approaches for the reduction of Green House Gas Emissions level and achieve national carbon emissions reduction targets. Carbon Emission Trading Schemes have emerged as one of the highly common system in the carbon market internationally, which offers various multifaceted accounting concerns (Warwick and Ng, 2012).

Accounting standard setters globally has made forethoughts on this emergent topic but still there is an absence of firm accounting standard to deal with carbon emissions accounting. Regardless of the fact that carbon trading is continue to be a popular topic, management of these issues continue to exist baggy and beset with challenges in the absence of understandable guidelines from the concerned authorities either Financial Accounting Standards Board (FASB) or the International Accounting Standards Board (IASB) on the approaches regarding carbon emission accounting in the books of the company even though IASB and FASB both have tried to tackle with this issue without any suitable solution in the in EITF 03-14, 2013 (Emerging Issues Task Force (EITF) and IFRIC 3 Emission Rights in 2004 by The International Financial Reporting Interpretations Committee (IFRIC).

This research scrutinizes the treatment for carbon emission allowances by the largest carbon producers in the EU Emissions Trading Scheme, which entails a thorough examination of their financial statements.

This research is pertinent for viable motives, explicitly that there are no standardized accounting treatments offered by the standard setters at present. 
Researches revealed that disclosures in the financial statements about the carbon emissions are not enough to discern the analogous disclosures relating to the comparative performance of corporations in the EU ETS(ACCA, 2009).

\section{Rationale of the Research}

This study is commenced to obtain pragmatic knowledge about carbon emissions allowances accounting under the EU Emissions Trading Scheme (EU ETS) by EU Companies. Scrutinizing emission allowances accounting methods is of crucial importance due to the monetary insinuation happening because of EU ETS that is highly substantial in temperament and value being the global leading carbon trading market sector. A research of the methods by which EU Companies account for carbon emission allowance under EU ETS would present valuable information to all of the stakeholders including governments and standard setters. The methods of accounting for carbon emission allowances espoused by EU Companies will also be of huge global significance due to the globalization of this scheme (Mokdee, 2013).

This research would be of attention to investors, international accounting standards organizations, carbon traders, auditors, academia and other stakeholders present worldwide who are or on the verge of taking part in their edition of cap-and-trade scheme.

\section{Research Aims and Objectives}

This study aims to cover the following objectives through this research:-

- Examination of the accounting methods of granted carbon emission allowances present in the financial statements of major EU Emissions Trading Scheme (EU ETS) emitters with the aim to ascertain inception knowledge of present accounting treatments.

- Evaluation of the accounting practices of EU organizations for purchased carbon emission allowances accounting in the absence of any authoritative guidelines.

- Assessment of the approaches of EU corporations for the accounting of their legal obligations to fulfill carbon allowances requirements.

- Propagation of the findings of this study to multiple audiences including academia and standard setters with the aim to elucidate the constitutional and institutional confrontations and chances that are present for leading the accounting methods and treatments of carbon emission allowances.

\section{Research Questions}

Specific areas of concern are as below:

1. How do the European Union companies are accounting for the allocated carbon emission allowances; both initial and subsequent measurement without any authoritative accounting guidance? 
2. How do the EU entities recognized trade carbon emission allowances in their accounts?

3. How do the European Union companies recognize their liabilities to surrender carbon emission allowances in order to fulfill legal obligations?

4. What could be the ultimate accounting approach to recognize carbon emission allowances in the books of European Union companies?

\section{Literature Review}

The European Union Emission Trading System (EU ETS)

The legitimately fastening obligations for EU participants were provided by the Kyoto Protocol to decrease Greenhouse Gas Emissions (GHG). In January 2005 , in order to achieve the target to trim down 20\% European Union's carbon emission by 2020 from 1990 altitudes, a cap-and-trade emission scheme namely EU Emission Trading System (EU ETS) which was the first largest carbon emission trading system (Point Carbon, 2010); entails every European member state to cap their emissions. Later, the Cap is transformed into carbon credits, which are also called 'European Union Allowances' (EUAs) which businesses are obliged to attain to cover their yearly carbon emissions from their installation and fitting activities. EU government officials apportion a predetermined amount of carbon credits at no cost to the companies (Warwick and $\mathrm{Ng}, 2012$ ). The statutory authorities have allocated almost $95 \%$ of carbon emission rights to the companies for free so far (ACCA, 2009). Giving up suitable figures of EUAs against the confirmed original carbon emissions could fulfill this requirement, as non-compliance incurs fines and penalties. On the other hand, businesses can freely trade their EUAs in the vigorously carbon emissions trade market where companies buy and sell their carbon rights in order to fulfill their carbon emission requirements (Bebbington and LarrinageGonzalez, 2008)In order to diminish the financial charge of its obligation to contest change in climate under Kyoto Protocol, EU countries have decided to arrange carbon emission credits market internally for the companies to trade CO2 rights (Eur-Active, 2009). As the key reason of establishing emissions trading system was to attain cost-beneficial and reasonably rational decrease in Greenhouse Gas Emissions. In addition, it offers emission credits worth that could be considered by businesses for investing capital or future business development and the emissions could be traded internally or externally in the carbon emissions trade market.

The EU ETS has been divided into three fulfillment phases:

- Phase I was introduced to generate the essential scientific infrastructure for carbon trading and its main purpose was to create awareness about the scheme and served as a learning phase for the period 2005 to 2007 where at least $95 \%$ of the carbon emission rights were allocated at no cost to the companies. 
- Phase II commenced with the pledge of Kyoto Protocol from 2008 to 2012 in which a nominal fine of $€ 100$ was imposed for each ton of carbon emissions produced that doesn't have compatible carbon allowances where the free carbon credits percentage was decreased to $90 \%$ (Warwick and $\mathrm{Ng}, 2012$ ).

- Phase III started from 2013 and will last until 2020 where additional public sale of carbon credits is intended under EC Directive 2009/29/ EC, almost $70 \%$ of carbon allowances will be sold by 2020 which would have a dramatic effect from accounting perspectives (ACCA, 2009).

Right holders may hold carbon credits for speculative trading motives besides the obligations to meet carbon emissions. Emission credits prices have been unstable since a couple of years ago especially from 2008 to 2010 (Capoor and Ambrose, 2009); it was €28 in July 2008, dropped down to $€ 8$ in February 2009 and then fluctuates in between $€ 10$ to $€ 15$ in May 2010 and finally came down to the lowest value of $€ 4$ in April 2013 (Carrington, 2013). This decrease in prices may have occurred due to economic downturns, which have resulted in lower production, hence less carbon emissions (ACCA, 2009). The subsistence of tradable carbon credits generates supplementary challenges for accountants though these carbon credits must be considered as a monetary item and should be documented and reported in the financial statements (Bebbington and Larrinage-Gonzalez, 2008).

\section{Carbon Emissions Allowances Accounting}

Where there are no precise accounting standards to apply to a case, then IAS 8 Accounting Policies, Changes in Accounting Estimates and Errors Para 10 is applicable. It states that management must employ its own judgment in adopting an accounting procedure, which forms reliable and relevant information in discussion with their auditors. This shows that the concerns related to carbon emission allowances accounting would be administered by multiple accounting standards including IAS 20 Government Grants and Disclosure of Government Assistance, IAS 2 Inventories, IAS 39 Financial Instruments: Recognition and Measurement, IAS 37 Provisions, Contingent Liabilities and Contingent Assets and IAS 38 Intangible Assets. As Emission Allowances are used for multiple causes, maybe they are held by the company just to follow the ETS requirements or for trading motives; vagueness about the nature of allowances in accounting practices arises whether they are an asset or a financial instrument? These concerns permeate logical debate by the accounting standard setters (ACCA, 2009).

The underlying principle is that accounting procedures should be uniform regardless of the use of emission allowances. IASB point of view regarding carbon emission accounting is that every accountant should treat it in a same way and there should be one precise method of accounting for carbon credits. IASB together with FASB are working on a project to determine the ambiguity adjoining the carbon emission allowances accounting. 


\section{Failure of IFRIC 3 'Emission Rights'}

With the aim of addressing the concerns in relation to carbon permits (EUAs), IASB asked the International Financial Reporting Interpretations Committee (IFRIC) to provide some guidelines on this issue. IFRIC 3 Emission Rights was issued late 2004, which recommended that liabilities and assets must be treated separately.

\section{Emission Allowances}

IFRIC 3 concluded that all carbon emission allowances must be accounted for as Intangible Assets, despite the consequences that they were held for free or bought from the carbon market and it should follow the disclosure requirements of IAS 38 Intangible Assets. Preparers of financial statements have two options to measure intangible assets: either cost method or revaluation method. Under the cost method to account for emission allowances, carbon credits are calculated at cost less amortization and impairment expenses. Where carbon emission allowances are bought and sold in the carbon market, revaluation method can be adopted, as the EUAs will meet the revaluation requirements. Under the revaluation method, carbon credits are recorded at its fair value with any profit margins recognized as a revaluation surplus in Equity in the Statement of Financial Position and any rise in the revaluation surplus have to be recognized as Other Comprehensive Income in the Statement of Comprehensive Income.

Furthermore, emissions allowances that is owed for lower than fair value must be treated primarily at their market price and the variance between the market price and the sum paid should be considered as a government grant, treated under IAS 20 Accounting for Government Grants and Disclosure of Government Assistance and primarily be identified as deferred income in the statement of financial position (SFP) and consequently accounted for as income over the fulfillment phase (Warwick and $\mathrm{Ng}, 2012$ ).

\section{Emissions Liability}

IFRIC 3 states that the liabilities to supply EUAs must be accounted for and a provision should be recorded under the guidance laid down in IAS 37 Provisions, Contingent Liabilities and Contingent Assets, which would also be calculated at market value. It was suggested that carbon emissions liability must be calculated at the best estimate value at the year-end of the required expenses to reconcile the current obligation. Usually it would be the market price of the figure of allowances necessary to pay off for the carbon emissions produced during the year and to be paid to the scheme commissioners in April of the subsequent year. Any alterations in the amount of a company's compulsion to give up carbon allowances to the scheme commissioners were recorded in the Statement of Comprehensive Income. Any offsets of the owned carbon credits and the obligation to give up carbon allowances are not allowed under IFRIC 3 (Warwick and Ng, 2012). 


\section{IFRIC 3 Accounting Disparities}

IFRIC 3 suggestions followed striking amount of controversies and considerable pessimistic reactions from the EU ETS members and huge carbon emitters had resulted in its complete withdrawal, where the negative backing opinion from The European Financial Reporting Advisory Group (EFRAG) gave a substantial load on IFRIC 3 withdrawal (Bebbington and LarrinangaGonzalez, 2008). The major oppositions not in favor of the usage of IFRIC 3 recommendations were the existence of accounting disparities in the standard that any surplus or deficits obtained by valuing liabilities has to be recorded in Statement of Comprehensive income, whereas any surplus or deficits arises from the revaluation of carbon emission credits has to be recorded in the Statement of Financial Position under Equity section. Commentators called this approach as a 'Mixed Presentation Model', which may result in probable volatility in the reported income (ACCA, 2009). In addition, the options to use variable accounting figures to recognize assets, some recorded at costs while other at the market value also caused issues of accounting mismatch (Cook, 2009). After the withdrawal of IFRIC 3 and in the absence of any international guidance on accounting for carbon emission allowances; a number of different practices have appeared (Mackenzie, 2009).

\section{Emission Trading Accounting Practices espoused by ETS Participants}

A number of studies have discovered the accounting practices of EU ETS members in reporting carbon emissions:

A research based on 26 key carbon emitters in the EU carried out by PricewaterhouseCoopers (PWC) and the International Emissions Trading Association (IETA) in 2007, notably influenced by the Kyoto Protocol and the EU ETS. The survey divulges the ambiguity and multiplicity of accounting approaches of the sampled companies that very few participants sustained to practice the inhibited IFRIC 3 Emission Rights as their preferred accounting approach. The majority of the respondents were using an approach to initially recognize allocated and traded allowances both at zero value as intangible assets in the Statement of Financial Position. These carbon allowances were neither subject to depreciate or amortize nor revalued after trading in the later run. In measuring the responsibility allied with the creation of carbon emissions, many participants related this on the net book value of allocated and traded allowances besides the remaining of the duty measured at the existing market value. Almost half of the participants adopted accounting practices excluding IFRS and many of them also reported under US GAAP (Mokdee, 2013).

Additionally, the International Emissions Trading Association (IETA) together with the Association of Chartered Certified Accountants (ACCA) in 2010, had undertaken a research based on 26 biggest Greenhouse Gas emitting 
EU Companies to ascertain a basic knowledge of how the largest emitters in Europe are accounting for carbon emissions they have produced. The research findings summarized that a substantial multiplicity in EU ETS emission allowances accounting approaches were practiced where majority of the companies were not using IFRIC 3 approach; only 11 companies recorded allowances as intangibles. The research revealed that in the $1^{\text {st }}$ and $2^{\text {nd }}$ Phase of the EU ETS, carbon credits were mainly recorded at zero value, which revealed that a third of the total assets in the company reports were recognized at zero value and very few companies adopted the IFRIC 3(ACCA, 2009).

In 2010, the data of 159 EU ETS companies in UK from the Phase 1 was used to explore the practices of carbon emission accounting before any accounting standards came into existence. The research revealed that only 21 companies had provided voluntary disclosures. Majority of the companies recognized carbon allowances as intangible assets or inventory and recorded at zero value. Many of them did not reveal any information about their accounting policies (Balatbat and Wang, 2010).

In 2011, another research has been conducted on 18 EU Companies who had released their accounting approaches in the financial statements. It was examined that $61 \%$ of the entities did not give disclosures on their accounting policy to recognize allocated and traded allowances whereas only $33 \%$ of the sample companies recorded it as intangible assets in their books (Steenkamp, Rahman and Kashyap, 2011).

The latest research conducted in 2012 in which 47 EU ETS carbon-emitting companies were examined. It was revealed that the highly widespread accounting practice to recognize allocated carbon allowances were intangible assets, whereas the rest did not disclose their accounting policies (Warwick and $\mathrm{Ng}, 2012$ ).

\section{Current Accounting Approaches for Carbon Emission Allowances}

Companies reporting under EU ETS remain puzzled about the appropriate accounting approaches for emission allowances. According to the research conducted by PricewaterhouseCoopers and the IETA, various accounting treatments were followed by the 26 sample entities [20]. Despite the fact that IFRIC 3 has been withdrawn, it can be examined that it continues to offer applicable guidelines for the accountants in the EU ETS to follow (Riley, 2007).

A number of accounting treatments for carbon emission allowances have developed in practice, notwithstanding, it can be combined into three major approaches.

\section{$\underline{\text { Remainder Value Approach }}$}

This approach is as similar to the guidelines given in IFRIC 3 with the deviation of liability recognition approach. The provision is founded on the purchase costs of the emission allowances currently held. The initial recognition of 
the intangible asset is recorded at market value along with the government grants as mentioned in IFRIC 3.

The provision is recorded to the extent that the company owns an adequate amount of carbon permits and is based on the carrying amount of those carbon emission allowances. Where the company does not have adequate amount of carbon permits, the liability must be recorded based on the fair value of those carbon emission allowances that are needed to fulfill the shortfall. If the company is not capable of obtaining sufficient emission allowances to fulfill its current obligation to surrender emission allowances, then a penalty will be incurred to the entity (Romic, 2010).

\section{$\underline{\text { Net Liability Approach }}$}

Under this approach, the carbon emission allowances allocated by the government are owned at nominal value only and the net obligation method is adopted to recognize provisions. No concept of deferred income recognition exists, when the emission allowances are obtained initially because the government grant is recorded at nominal value (which is a Nil Value) in accordance with the guidelines set out in IAS 20 Accounting for Government Grants and Other Government Assistance. This approach seems quite reasonable in the absence of precise guidelines by the accounting standard setters (Dellaportas, 2010). This method is considerably less complex as compared to the approach recommended by IFRIC 3 (Riley, 2007). According to Ernst \& Young, This approach records traded carbon allowances in the same way as other intangible assets (Mokdee, 2013).Allocated emission allowances are used to counterbalance any obligation arises due to the carbon emissions. For this reason, no requirement of entries exists, on condition that the company possesses adequate carbon emission allowances to fulfill its current obligation to surrender carbon emission allowances.

On occasion where the company does not have sufficient emission allowances or have no allowances at all to fulfill its present obligation than a liability in the form of provision is recorded at the best estimate of the value of expenses to be incurred to fulfill its carbon emission allowances obligation such that the cash value of the original allowances needed to fulfill the deficit of the company's current obligation at the fair value on the reporting date (ACCA, 2009).

A strong practice headed for the net-liability method of accounting for carbon allowances by the carbon emitters is going on in Europe (Fornaro, Winkelman and Goldstein, 2009). On the whole, the Net liability approach is a renowned method with approximately $70 \%$ of all entities is following this approach (Romic, 2010).

\section{Research Methodology}

This research will be conducted by adopting a qualitative research approach as we are working to gain knowledge about the importance and the accounting 
practices of carbon emission allowances by the carbon emitters in Europe. Also, to understand the necessity of carbon emission accounting authoritative standard guidelines in accounting practices (Ayaz, 2013). This research method typically follow rich data sample but cannot oversimplify to the entire population and the motive of this research is not to simplify, but to a certain extent gain detail knowledge about the current accounting practices in carbon market. Qualitative research technique is explained as an assortment of explainable procedures which request to illustrate, decipher, interpret or else come to expressions with the sense, and not the regularity, of some approximately obvious resulting phenomena in the communal world. Additionally, this technique seeks to obtain knowledge about public's interpretations given that the reality is what public recognize it to be (Key, 1997).

The fortitude of a research method is primarily reliant on the researcher's epistemological and ontological point of view on realism and the way an understanding can be created. Moreover in the fortitude of the procedural arrangement, the didactic background of the researcher and the research group impact on the researcher is believed to be the most significant aspects. Ontology is an effort to gain knowledge about the realism of the active world and epistemology is the viewpoint that focuses on the reasons behind the recognition of this communal reality and about the identification of the known persons about this realism. The ontological and epistemological place of the person carrying out the research outlines all characteristics of research procedure with selecting the topic, establishment of research aims and questions, methods of sampling and design of the research (Hesse-Biber and Leavy, 2011).All of the carbon emissions accounting concerns and the carbon market without the presence of a precise accounting standard are ontological arrangements in this research. The existing carbon accounting treatments by the carbon emitters can be investigated from the financial statements of those entities and the perusal of literature. Fundamental grounds of the existing treatments can be discovered from practitioners and rising accounting treatments can be searched by professionals' explanations and appraisal. Research findings would be fashioned by evaluating notes to the financial statements originated in archival data search of company records that are publicly available.

\section{Research Design}

The qualitative research depicts an inductive approach and focuses on generating idea [6]. With the intention to make sure that the substantiation gained was able to respond to the preliminary questions as unmistakably as possible, the research commence with the disclosures about the carbon emission accounting practices in the notes to accounts imitated in annual reports of 2009. It is to discover how the carbon emitters are accounting for granted and traded carbon emissions allowances. 


\section{Content Analysis}

Content analysis methodology is adopted in this research to gain knowledge about how EU ETS participants account for emission allowances by examining their accounting practices and approaches revealed in their publicly available financial statements. This analysis approach is methodical and intent method for recapitulating written, publicly available and documented contents (Colton and Covert, 2007). Content Analysis codifies quantitative and qualitative data into pre-stated groups so that the final information will be presented in a format, which outlines easy presentation and treatment of data. In order to make it more effective, few methodological requirements must coincide, for instance, analysis units (Guthrie and Abeysekera, 2006).

\section{$\underline{\text { Unit of Analysis }}$}

It is the part of some kind of communicating content that may relates to verdicts, statements, subjects, parts or images contained in that content later it has been created (Walter, 2006). Whilst this methodology is espoused in accounting prose, researchers have options either to calculate total disclosures presented or scrutinize the degree of those disclosures (Gray, Kouchy and Lavers, 1995). This research focuses on the figure of meticulous accounting approaches practiced by EU ETS entities concerning carbon emissions allowance accounting. The unit of analysis for this research is the publicly available financial statements of EU ETS companies. Alternatively, questionnaires or feedback form might have been used to gather required information as a primary data collection means but financial statements symbolize externally verified medium of data collection that is simply and professionally available from Internet sources or in paper forms. These are the most important basis of data collections for any analysis in the accounting practice as it depicts company's actions and steps that it has taken during the period and is open for examination by its stakeholders (Warwick and $\mathrm{Ng}, 2012$ ).

\section{Coding of Emissions Related Accounting Disclosures}

In order to conduct the coding analysis technique, the appropriate parts of financial statements of the sample companies were traced to Word document from their annual reports to apply coding with some reformations. Appendix 1 shows the recapitulated appropriate disclosures. These files were amalgamated after which the actual 2 segmented coding process begun.

The original research questions had elaborated the significance of acquiring knowledge about the accounting for 'allocated carbon emission allowances' by EU emitters (research question 1), 'traded carbon emission allowances' (research question 2) and liability to give up emission allowances (research question 3). Nonetheless, the research questions had approached two significant characteristics that how the EU carbon emitters categorize the transactions according to its specific nature either an asset or a liability and the rate the emitting companies 
allot to that particular subject. A numeric code was allocated to every accounting disclosure pertinent to every research question to make coding process troublefree. The coding ' $\mathrm{R} 1$ ' is assigned for granted carbon emission allowances including asset and liability disclosures, which relates to research question 1. ' $\mathrm{R} 2$ ' is assigned for purchased carbon emission allowances, which comes under research question 2 and ' $\mathrm{R} 3$ ' for the obligation to surrender emission allowances, which is research question 3. For example; a disclosure presented in a company's financial statement that 'Traded carbon credits are originally recorded at cost price within intangible assets', as this statementis applicable to research question 2 and therefore given a code ' $R 2$ '. The answers offered in the financial statements for all assigned numeric code were then traced simultaneously to make reaction sheet for the next phase of coding analysis (responses by the sample entities for code 'R1', 'R2' and 'R3' are presented in Appendix 1). The resultant answers later merged together in terms of their similarities in accounting practices and hinted by the use of few terms that abridged that accounting practices. Thus, four key words 'inventory', 'asset', 'intangible asset' and 'not disclosed' were assigned for code ' $\mathrm{R} 1$ ' relating to the allocated emission allowances asset arrangement. Where no information is provided in the disclosures regarding carbon emission allowance, 'not disclosed' code word helps to gain understanding about non-disclosures by the entity. Finally, all the related codes were analyzed and then separated into different tables to make it easy for the readers to understand the correct responses under each tables rather than confusing with understanding codes (Warwick and $\mathrm{Ng}, 2012$ ).

\section{Sample Selection}

Non-Probability sampling approach is used in this qualitative approach to study, as it is based on a statistical data but you can still simplify samples from the entire population (Saunders, Lewis and Thorn Hill, 2007). The highly carbon emitting EU companies has been selected due to their significance over the total sample. Other sampling techniques were not suitable for this study, as they fit best with probability sampling techniques being based on a large sample of data.

The Carbon Monitoring for Action (CARMA) catalogue was considered for selection after analyzing multiple likely databases as it is funded by the Centre for Global Development which was ranked fifteenth out of hundred of entities among the world's leading 'think tanks' (CARMA, 2014). The database highlights the largest and smallest carbon emitters globally. As this research is focused in Europe sector; CARMA's record has provided over 7,000 power companies in Europe that produce carbon emission and from the total, the uppermost ranked 97 carbon producing entities were considered as the sample size for this research.

Sample has been selected on the basis of highest carbon producers and not based on random sampling technique. It is because smaller carbon emitting companies are less likely to reveal any information about carbon emission accounting, cause their activities less effect the environment in comparison. 
Thus, random sampling would have ended up giving a wrong population, which would have resulted in arbitrary conclusions.

After the sample selection, next step was to identify a fiscal year end for this research. The financial statements of 2009 year-end were selected as most of the prior studies have already conducted researches using 2007 and 2004 year-ends after the completion of first and second phase of EU ETS. Financial statements of 2009 were the latest reports available at the time of data collection. In order to obtain appropriate set of disclosures to include in this research findings, the criteria for final selection of the sampled entities to derive conclusions were as follows:

- All the financial statements must be in English, as the researcher does not have command on other European languages; therefore, all annual reports in a language other than English were ultimately rejected from the sample.

- All the financial statements must be available as an electronic file on the websites or other Internet portals and available for general public.

- All the financial statements must reveal practices of accounting for carbon emission allowances by the carbon emitting companies.

\section{Graphical and Descriptive Figures of the Sampled Entities}

A table has been made to illustrate the selection and expulsion of the 97 sampled entities for the final conclusions presented in Figure: 1.

Figure 1. Analysis of Total Sample Entities

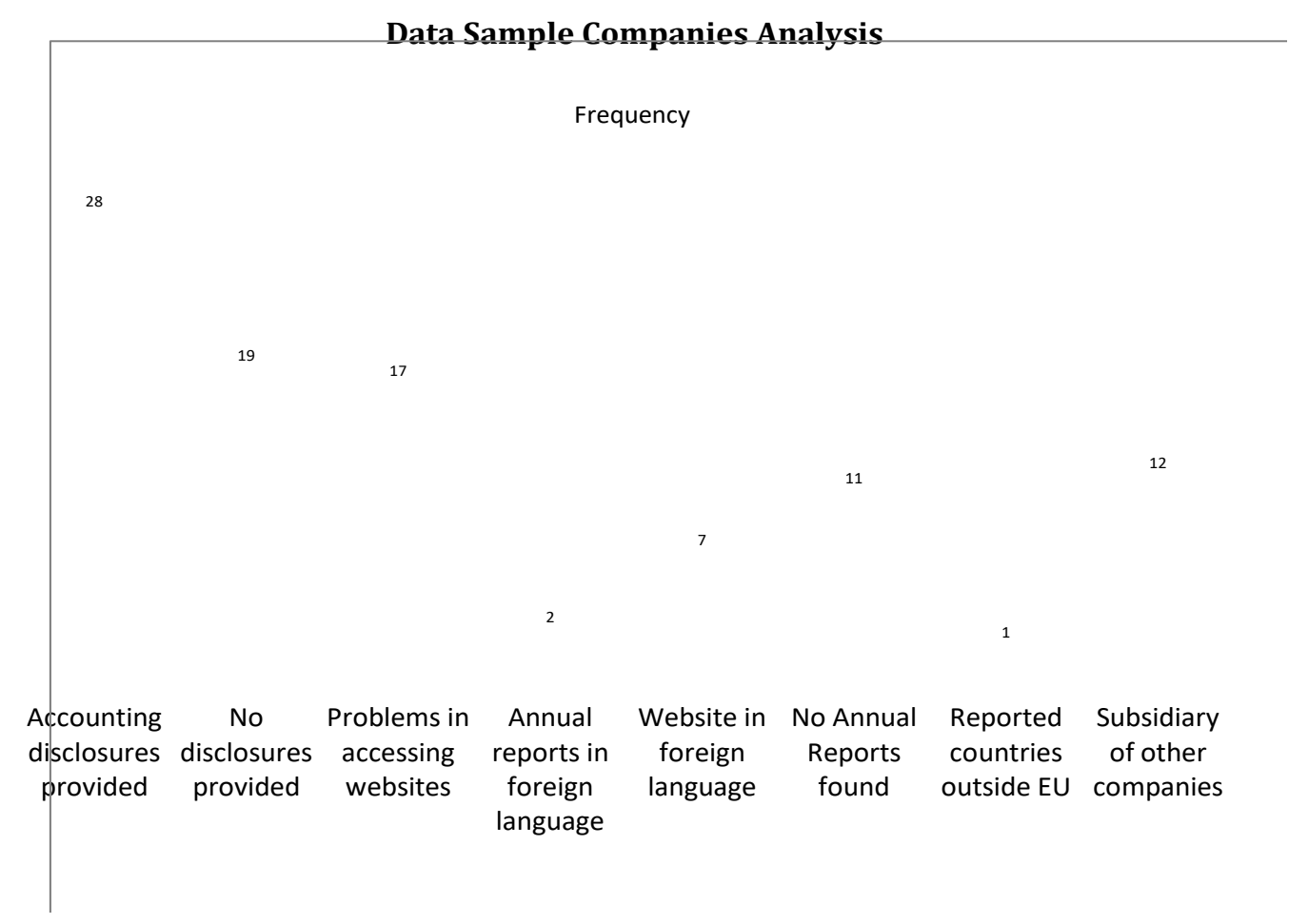


From the sample of 97 companies, 28 companies met the final selection criteria. The rest of the companies were expelled from the sample because 19 companies did not provide any disclosures, 17 companies did not own a website through which electronic files could be downloaded to use in this study and 12 companies were considered to be subsidiaries of other entities and therefore, did not present financial reports separately. Also, 2 companies presented financial statements in foreign languages, which is why they were excluded from the final selection, 7 company's websites were in foreign languages and 1 company was expelled from the final sample selection cause their headquarter is based abroad.

Table 1. Total EU Countries embodied in the chosen Sample for this Research Companies across the Companies selected in this

\begin{tabular}{|c|c|c|c|c|}
\hline \multirow[b]{2}{*}{ Country } & \multicolumn{2}{|c|}{$\begin{array}{l}\text { sample } \\
\mathrm{N}=97\end{array}$} & \multicolumn{2}{|c|}{$\begin{array}{c}\text { research } \\
\mathrm{N}=28\end{array}$} \\
\hline & Frequency & $\%$ & Frequency & $\%$ \\
\hline Austria & 2 & $2.06 \%$ & 2 & $7.14 \%$ \\
\hline Belgium & 1 & , & - & $0 \%$ \\
\hline Bulgaria & 1 & $1.03 \%$ & - & $0 \%$ \\
\hline Croatia & 1 & $1.03 \%$ & - & $0 \%$ \\
\hline Cyprus & 1 & $1.03 \%$ & 1 & $3.57 \%$ \\
\hline Czech Republic & 4 & $4.12 \%$ & 2 & $7.14 \%$ \\
\hline Denmark & 1 & $1.03 \%$ & 1 & $3.57 \%$ \\
\hline Estonia & - & $0 \%$ & - & $0 \%$ \\
\hline Finland & 9 & $9.27 \%$ & 2 & $7.14 \%$ \\
\hline France & 4 & $4.12 \%$ & 2 & $7.14 \%$ \\
\hline Germany & 22 & $22.68 \%$ & 5 & $17.85 \%$ \\
\hline Greece & 3 & $3.09 \%$ & - & $0 \%$ \\
\hline Hungary & 4 & $4.12 \%$ & 1 & $3.57 \%$ \\
\hline Ireland & 5 & $5.15 \%$ & 1 & $3.57 \%$ \\
\hline Italy & 8 & $8.24 \%$ & 3 & $10.71 \%$ \\
\hline Latvia & 1 & $1.03 \%$ & - & $0 \%$ \\
\hline Lithuania & 1 & $1.03 \%$ & - & $0 \%$ \\
\hline Luxembourg & - & $0 \%$ & - & $0 \%$ \\
\hline Malta & 1 & $1.03 \%$ & 1 & $3.57 \%$ \\
\hline Netherlands & 1 & $1.03 \%$ & 1 & $3.57 \%$ \\
\hline Poland & 3 & $3.09 \%$ & - & $0 \%$ \\
\hline Portugal & - & $0 \%$ & - & $0 \%$ \\
\hline Romania & 4 & $4.12 \%$ & - & $0 \%$ \\
\hline Slovenia & 2 & $2.06 \%$ & 1 & $3.57 \%$ \\
\hline Slovakia & 1 & $1.03 \%$ & - & $0 \%$ \\
\hline Spain & 5 & $5.15 \%$ & 2 & $7.14 \%$ \\
\hline Sweden & 1 & $1.03 \%$ & - & $0 \%$ \\
\hline United & & & & \\
\hline Kingdom & 11 & $11.34 \%$ & 3 & $10.71 \%$ \\
\hline Total & 97 & $100 \%$ & 28 & $100 \%$ \\
\hline
\end{tabular}


Table 1 illustrates the demonstration of carbon emitting companies in each EU country in the sample of 97 corporations selected for this research. The chart includes all 28 European Union countries of which 26 are embodied in the initial data sample, which covers roughly all countries to be integrated in this research finding. Of those 26 countries, only companies in 15 countries revealed disclosures about carbon emission accounting that were applicable to this research. By including a large percentage of EU countries in this study, final conclusions drawn from this research will be convincing to review the approach of EU countries to account for carbon emission permits.

\section{Data Analysis}

Electronic copies of 28 businesses' financial reports that met the final sample selection criteria were downloaded and examined to discover only carbon emission accounting related disclosures and the accounting treatment that the company follows to treat emission permits in their accounts. 'Notes to the financial statements' were the most obvious part in the annual reports where desired information could be located but in order to keep an eye on each and every sentence related to carbon emission accounting, search has been made in the downloaded PDF files using the 'Search' option with the key terms including 'emissions', 'C02', 'allowances' and 'carbon'. These keywords are mainly related to any information presented regarding carbon emission allowances and are used most frequently in this topic of study. 'Search' option in Adobe Files is the most helpful tool by which you can see and read each and every sentence where the key word has been used in the content. By using this tool, reader would hardly be able to overlook any disclosures about the desired context. Also, paragraph skimming sometimes results in important information being overlooked by the reader.

\section{Research Findings}

The research findings are presented in tables to demonstrate the trends and multiplicity in accounting practices throughout Europe.

\section{Allocated Carbon Emission Allowances}

Analysis of the sample revealed that 11 companies are recognizing national allocated emission allowances in their accounts as intangible assets, which is $39.2 \%$ of the total sample (see Fig. 2). Only 1 company has recognized allocated carbon permits as inventory, which is $3.57 \%$ of the total sample and marginally consistent with the findings by Lovell et al., 2010 and Warwick and $\mathrm{Ng}, 2013$. 
Figure 2. Recognition of allocated Emission Allowances in the Books of EU Companies

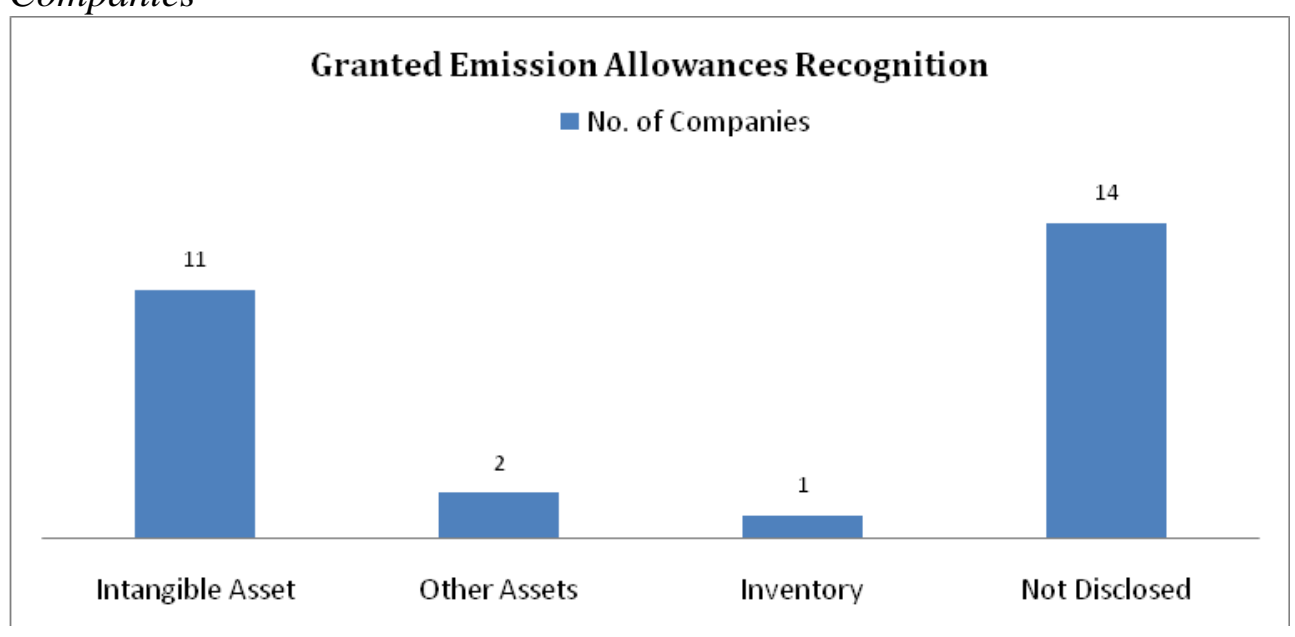

Nonetheless, $50 \%$ of the companies did not reveals any information about the allocated emission permits which is surprisingly very high percentage by considering the fact that the sampled entities in this research were the largest carbon producing companies among all other companies in Europe, hence, the figures of allowances would be highly material. Though we cannot ignore the fact that after IFRIC 3 has been withdrawn, there is no precise guidance from the accounting standard setters regarding emissions accounting which could be one the reasons that many companies have chosen not to disclose any information related to it.

Table 2. Multiple Approaches in valuing Allocated Carbon Emission Allowances by the EU Companies

\begin{tabular}{lll} 
& Frequency & Percentage \\
\hline Nil Value & 5 & $17.85 \%$ \\
Market/Fair Value & 5 & $17.85 \%$ \\
Nominal Value & 3 & $10.71 \%$ \\
Cost & 4 & $14.28 \%$ \\
Not Disclosed & 11 & $39.28 \%$ \\
Total & 28 & $100.00 \%$
\end{tabular}

Despite the fact that the allocated carbon emission allowances are mainly recognized as intangible assets, the techniques of recognizing these permits are greatly diverse. Ambiguity in disclosures has been found due to the wordings used in providing disclosures for example, an entity reveals that it recognizes allocated emission allowances at 'Zero Value' but the other entity states 'Nominal Value' which is indeed 'Nil Value' and thus creates ambiguity.

Upon analyzing the methods of accounting for allocated emission allowances, it was observed that majority of the companies have recorded it at 'Zero Value' on initial recognition together with 'Fair Value' with the similar percentage repeatedly used approach. $14.28 \%$ of the sample companies have recorded it at 
cost and around $11 \%$ at nominal value whilst a greater proportion of companies $39.28 \%$ have chosen not to disclose an accounting approach for these allowances (see Table II). The research findings highly deviates from the most recent research by Warwick and $N g 2013$ according to which majority of the companies have recorded granted emission allowances at 'Nil Value' as it is identified that same percentage of the companies record it at 'Nil Value' and 'Fair Value' followed by recognition at 'Cost' as a second highly used practice.

Considering the fact that the sample entities are the largest carbon emitters in the EU ETS, non disclosure of 11 out of 28 companies is relatively high which creates vagueness in comparability of multiple companies annual reports. The most obvious reason for not disclosing any valuation method for carbon emission allowances would be the withdrawal of IFRIC 3 after which no publication of any accounting standard came into existence by the accounting standard setters, which would have brought uniformity in accounting practices.

\section{Traded Carbon Emission Allowances}

EU ETS participating entities buy carbon emission permits either to overcome the shortage of granted emission allowances if they anticipate that additional allowances would be needed to balance their yearly carbon emissions or to trade in carbon market in the means of forward contracts for example. Though the main reason for emission allowances trading was to fulfill their legal obligations (Warwick and $\mathrm{Ng}$, 2012).Traders of carbon emission allowances who own carbon permits for auction in the normal course of business must account for it as inventory as stated in IAS 2 Inventories. Whereas according to IAS 39 Financial Instruments, traded carbon emission permits must be recognized at 'Market Value' with any surplus or deficit in trading should be reported in the income statement.

Figure 3. Traded Emission Allowances Initial Recognition

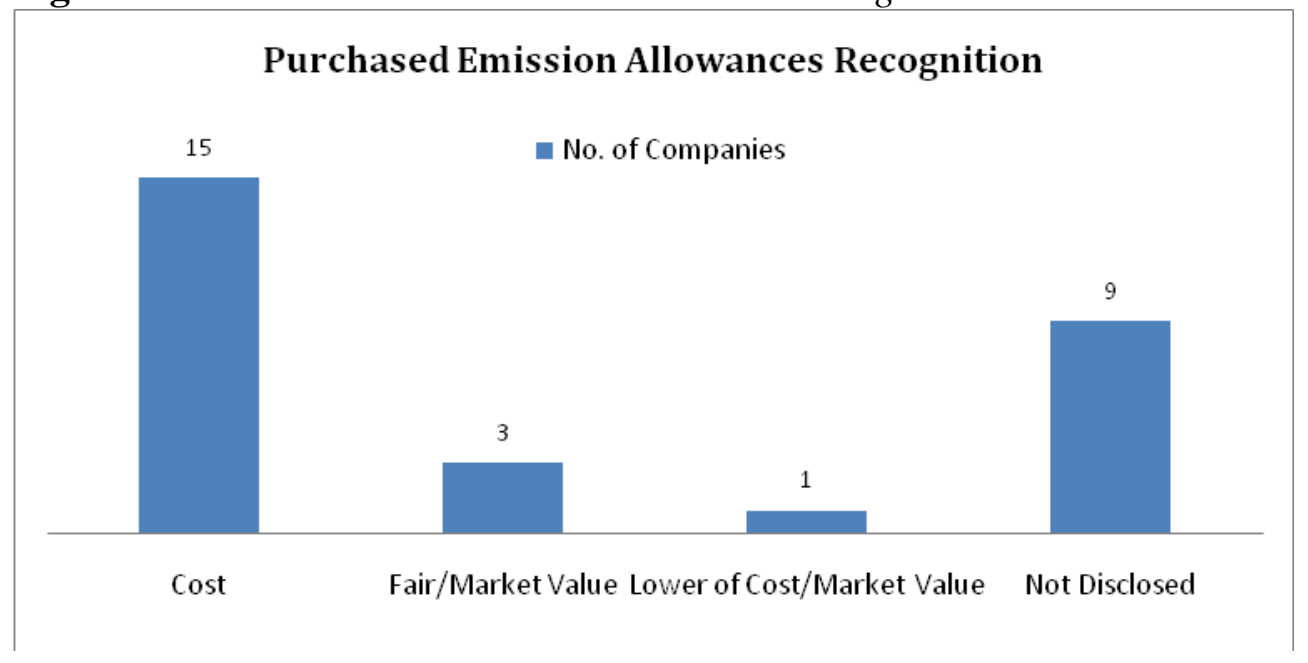

The current research only scrutinized purchases of carbon permits for the motive given that majority of the sample entities apprehended carbon permits 
to fulfill their legal obligations. Research reveals that 19 companies that has presented disclosures for the recognition of traded carbon permits, of them, 15 companies recognized them at 'Purchase Price/Cost', 3 companies at 'Market Value' whereas 1 company has the policy to recognize purchased emission allowance at the lower of market value or cost at the balance sheet date which can be seen in Fig. 3. This leading approach to recognize traded emission allowances at purchase price is as same as historical cost convention method.

Table 3. Carbon Emission Allowances Subsequent Measurement at the Balance Sheet Date

Market Value

Frequency Percent\%

Fair Value Measurement, or written down if lower

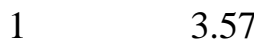

than Carrying Amount

Lower of Cost or Market Value

Cost

At Cost less Impairment Losses

No Disclosure

Total

The disclosures regarding the initial recognition of traded allowances are relatively consistent whereas the disclosures concerning the recognition of these allowances at the yearend expose a reverse movement. The research finding shows that only 7 out of 28 companies who revealed emission allowances subsequent recognition approach; disclosed multiple approaches to recognize these allowances in the later run which can be seen in Table III. Without the presence of precise guidance from the accounting standard setters, no uniformity of subsequent measurement was observed in the sample entities annual reports. Due to this reason, disclosures were not presented in relation to traded emission allowances by many companies which can be identified from Figure 3 that most of the companies revealed that they had bought carbon permits.

\section{Obligations for Emissions Produced}

EU ETS participants are required to give up one carbon permit for every ton of carbon emissions released throughout the year to their scheme commissioners. According to IAS 37 Provisions, Contingent Liabilities and Contingent Assets, entities are obliged to recognize the liability to surrender emission allowances as equal to original emissions released as a provision in their accounts because of the reason that companies give up equivalent allowances for additional emissions produced in next fiscal year. 
Figure 4. Recognition of Obligations to Surrender Emission Allowances

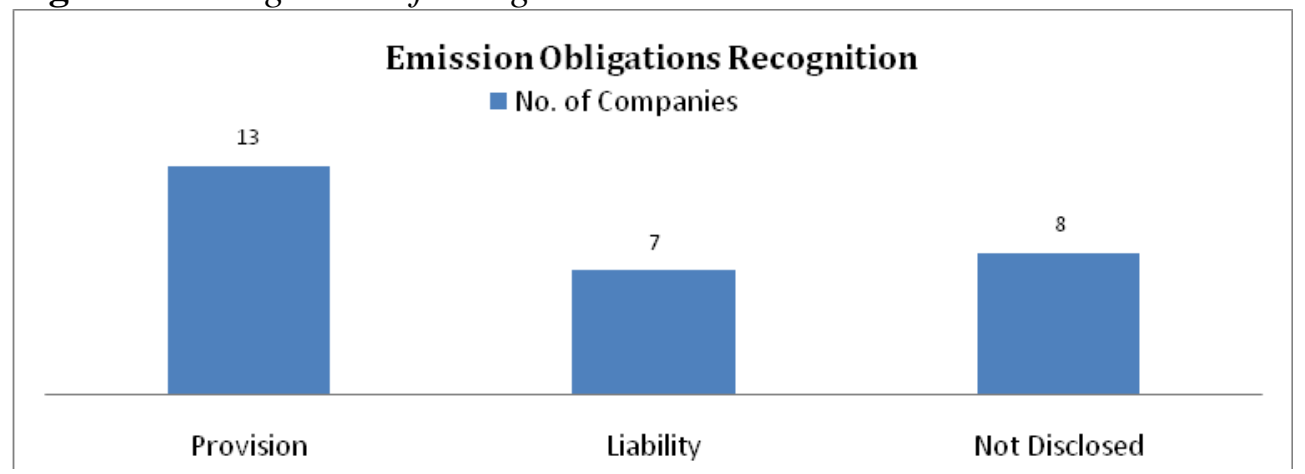

It can be observed from Figure 4 that a mass of the entities recorded their obligation to give up additional allowances as liabilities or provisions in their accounts except 8 companies who did not pursue the guidance of IAS 37 and instead did not disclose anything in their financial statements in settlement of their emissions obligations.

Table 4. Owned Emission Allowances Measurement

Cost of traded allowances

Carrying amount of allowances

Acquisition cost (forward markets)

Capitalized at Costs

Market value - Pro-rata basis

Balancing entry - Net Obligation

Net liability method

Book value of allowances capitalized

No disclosures

Total

\section{Frequency}

3

3

2

1

2

1

1

1

14

28

\section{Percentage}

$10.71 \%$

$10.71 \%$

$7.14 \%$

$3.57 \%$

$7.14 \%$

$3.57 \%$

$3.57 \%$

$3.57 \%$

$50.00 \%$

$100.00 \%$

Without the presence of appropriate guidelines from the accounting standard setters, an entity may recognize carbon permits as an asset at a value and the obligation to give up the same carbon permits at another value in subsequent measurement. The study disclosed that entities follow two distinctive recognition approaches for this liability; the cost of carbon permits remaining at the yearend either allocated or traded and the cost of additional allowances needed to fulfill the estimated obligations. It is identified that 14 companies reveals the methods to measure the liability of emission allowances remaining at year-end (see Table IV), which reveals a variety of treatments for valuing this liability. On the whole, the liability to give up carbon credits in the form of allowances owned emerges to be valued mainly at either the purchase price or the net book value of traded allowances. 
Table 5. Remaining Emission Allowances Measurement

Market price

Market price at the-

balance sheet date

Net liability method, valued at Fair Value

Fair value on the reporting date

No disclosures

Total

$\begin{array}{cc}\text { Frequency } & \text { Percent\% } \\ 4 & 14.28 \% \\ 7 & 25.00 \% \\ & \\ 1 & 3.57 \% \\ 2 & 7.14 \% \\ 14 & 50.00 \% \\ 28 & 100.00 \%\end{array}$

Table $\mathrm{V}$ shows that 7 companies recognizes the shortfall of the emissions obligations at 'market price at the reporting date' whereas 4 companies disclosed this figure as the 'market value' which might have the same illustration but again it may well not be the case. For this reason, the key word 'at' might relate to fair value of emission allowances in the carbon market over a passage of time at the end of the balance sheet date. It is also observed that in many cases, the fair value of carbon permits in Carbon market was used.

\section{Conclusion}

This research was conducted in order to obtain knowledge about the accounting practices of EU ETS companies for carbon emission allowances in 2009. It was observed that there was multiplicity of accounting treatments for carbon emission permits. Certainly, EU ETS major carbon emitters espoused a miscellany of accounting approaches for carbon emission allowances accounting in their accounts. The study has revealed that the sample entities have a propensity to recognize allocated emission allowances as intangible assets in their financial statements at zero value upon initial recognition. They record traded emission allowances at purchase price on initial recognition, whereas subsequent measurement is followed without any trends. The entities record provision or liability in their accounts for the legal obligation to surrender emission allowances at either net book value or at costs remaining at the balance sheet date and any remaining allowances at the fair value at the balance sheet date.

It was identified that sample entities were not following IFRIC 3 guidelines as consistent with the findings of Lovell et al., 2010 and Warwick and Ng, 2013. For instance, majority of the entities recognized the allocated emission allowances at zero value and market value but not the high percentage has recognized it at Market Value as recommended by IFRIC 3. On the other hand, some of the disclosures found were consistent with the guidelines set out in IFRIC; $39.2 \%$ of the sample entities have measured carbon emission allowances as intangible assets and measurement of the legal obligation to give up emission allowances as a liability or provision for example. Though this provision should be recorded at the best estimation at the balance sheet date as recommended by IFRIC 3, 
sample entities mainly valued the emission allowances at cost price and the remaining liabilities at fair value.

These research findings could be of interest to international accounting standard experts, government or other supervisory bodies, investors, academia, etc. Though the International Accounting Standards Board supported IFRIC 3 recommendations as a 'suitable interpretation 'of current accounting standards, it furthermore recognized that the article 'fashioned inadequate valuation and creates accounting mismatches' (Warwick and Ng, 2012). IFRIC 3 recommendations were based on the accounting for carbon emission allowances by individually taking into account the allocated emission allowances nature and the liability to fulfill the legal obligation to surrender emission allowances (Cook, 2009). In a theoretical viewpoint, carbon permits are assets according to IAS 1 Framework for the Preparation and Presentation of Financial Statements because carbon allowances are controlled by the entity as a result of past practices and due to which financial benefits are expected to flow to the entity (Warwick and $\mathrm{Ng}$, 2012). Conversely, whether carbon emission allowances are financial instruments or intangible assets, IFRIC 3 suggested that they are indeed intangible assets and must be measured in reference to IAS 38 Intangible Assets by initial recognizing at market price with the variation between market value and the cost price should be recognized as a government grants and must be measured in accordance with IAS 20 Government Grants and Other Government Assistance. In relation to the liability, IFRIC 3 suggested that the legal obligation to surrender emission allowances equals to original emissions released must be recorded under liabilities as a provision in accordance with IAS 37 Provisions, Contingent Liabilities and Contingent Assets. Despite the consequences whether these approaches were conceptually well, the IASB faced momentous disapproval from the stakeholders. Yet, it was advised to the accounting standard experts to oppose the enticement to determine each and every accounting concern by instituting a uniform standard, instead to offer precise application of an opinion in the theoretical and conceptual framework (Cook, 2009).

Secondly, the absence of authoritative accounting guidelines has revealed the multiplicity of accounting treatments being followed among the EU ETS companies, which has resulted in complexities in comparing company's performances together. It is also very difficult for auditors to provide assurance on the accounts when a diversity of accounting standards has been practiced among all companies. Auditors problems in dealing with emission accounting can be more illustrated by a perusal of an exposure draft ISAE 3410 Assurance Engagements on Greenhouse Gas Statements which International Auditing and Assurance Standards Board has issued in this context.

\section{Research Limitations}

Despite all above, a lot of limitations may have added to the research findings mainly because all of the companies in EU ETS were not included in the sample data for this study as it would take a great deal of time and wouldn't 
be possible to consider within the given timeframe. This was an investigative research by considering 2009 yearend data only. It was decided that only those annual reports of the sample entities will be selected for the analysis that were presented in English and reports in other languages will be excluded from the study which by inclusion in this study could have resulted in varied trends. Substantial attempts were made to find out the websites and financial statements for all companies in the data sample but few reports and websites were not found due to which those companies have been excluded from the final data, again, the trends could have been different by including those companies. Nonetheless, non-random sampling technique may have a potential to researchers bias and subjective judgments but the highest emitters were selected in this study by considering the materiality of the values in relation to other companies in EU ETS.

\section{Potential Research Area}

Carbon emission allowances accounting is potentially a new subject topic. The current research has disclosed that a lot of entities are not revealing their accounting practices and methods for emission allowances. Future study could take account of surveys and questionnaires of the target companies that do not disclose much about this subject in their financial statements in order to obtain deeper knowledge of their views and reason for opting either not to disclose or if they deal with it outside the financial statements than to enquire those practices with justifications.

\section{References}

Association of Chartered Certified Accountants (2009) Carbon accounting: too little too late. Available at: http://www.accaglobal.com/content/dam/acca/global/PDFtechnical/climate-change/tech-tp-tlt.pdf (Accessed $8^{\text {th }}$ Jan 2014).

Ayaz H (2013) The importance of trans-disciplinary sustainability accounting in professional accountancy discourse. Available at: http://www.academia.edu/531 7520/The_Importance_of_Transdisciplinary_Sustainability_Accounting_in_Profe ssional_Accountancy_Discourse (Accessed $18^{\text {th }}$ Feb 2014).

Balatbat MC and Wang W (2010) Voluntary disclosure of accounting policies for the treatment of carbon emission permits: The UK EU-ETS case. Centre for Social and Environmental Accounting Research: 1-30.

Bebbington, J and Larrinaga-Gonzalez C (2008) Carbon Trading: Accounting and Reporting Issues. European Accounting Review. 17(4): 697-717.

Capoor K and Ambrosi P (2009) State and Trends of the Carbon Market. Report, The World Bank, Washington D C, May.

Carrington, D., 2013. Carbon fat cats are killing the emissions trading mouse. The Guardian, 14 February, 13.

CARMA (2014) Power Companies. Available at: http://carma.org/dig/show/world +company (Accessed $10^{\text {th }}$ Jan 2014).

Colton D and Covert R W (2007) Designing and Constructing Instruments for Social Research and Evaluation. San Francisco: John Wiley and Sons. 
Cook A (2009) Emission rights: From Costless Activity to Market Operations. Accounting, Organizations and Society 34(4): 456-468.

Dellaportas G (2010) Accounting for Carbon. In: Australia Institute of Chartered Accountants. Available at: https://www.charteredaccountants.com.au / /media/Fi les/Industry\%20topics/Reporting/Climate\%20Change/Accounting\%20for\%20car bons.ashx. (Accessed 11 ${ }^{\text {th }}$ Jan 2014).

Deloitte (2009) Carbon Accounting Challenges: Are you ready? Available at: http:// www.deloitte.com/assets/Dcom-UnitedStates/Local\%20Assets/Documents/Ener gy_us_er/us_er_NewChallengesinCarbonAccounting_1009.pdf (Accessed $7^{\text {th }}$ Jan 2014).

Elfrink J and Ellison M (2009) Accounting for Emission Allowances: An Issue in Need of Standards. The CPA Journal. 79(2): 68-71.

Ellerman A and Buchner B (2008) Over-Allocation or Abatement? A Preliminary Analysis of the EU ETS Based on the 2005-06 Emissions Data. Environmental and Resource Economics, 41(2): 267-287.

EurActiv (2009) CO2 Emissions fell by $11 \%$ in 2009. Available at: http://www.euractiv. com/climate-environment/eu-co2-emissions-drop-11-2009-news-403298 (Accessed $9^{\text {th }}$ Jan 2014).

Fornaro J, Winkelman K and Goldstein D (2009) Accounting for Emission: emerging issues and the need for global accounting standards. Journal of Accountancy, 208(1): 40-47.

Gray R, Kouhy R and Lavers S (1995) Constructing a Research Database of Social and Environmental Reporting by UK Companies. Accounting, Auditing \& Accountability Journal 8(2).

Guthrie J and Abeysekera I (2006) Content Analysis of Social, Environmental Reporting: What is New? Journal of Human Resource Costing \& Accounting 10(2): 114-126.

Hesse-Biber SN and Leavy P (2011) The Practice of Qualitative Research. London: SAGE Publication.

Key JP (1997) Research Design in Occupational Education. Masters Thesis, Oklahoma State University, USA.

Krupova L and Cerny M (2007) The Net Liability Approach for Emission Allowances. European Financial and Accounting 2(1): 54-70.

Lovell H, Bebbington J and Larrinaga-Gonzalez C (2010) Accounting for Carbon. In: ACCA Global. Available at: http://www.accaglobal.com/content/dam/acca/glo bal/PDF-technical/climate-change/rr-122-001.pdf (Accessed 21st January 2014).

MacKenzie D (2009) Material Markets: How Economic Agents are constructed. Oxford: Oxford University Press.

McGann J (2009) The Think Tank Index. Foreign Policy Magazine, May, 09.

Mokdee T (2013) Accounting for Carbon Emission Trading: An Australian Perspective. $\mathrm{PhD}$ Thesis, RMIT University, Australia.

PricewaterhouseCoopers and International Emissions Trading Association (2007) Trouble-Entry Accounting - Revisited. Available at: http://www.ieta.org/assets/ Reports/trouble_entry_accounting.pdf (Accessed 1st February 2014).

Point Carbon (2010) Carbon 2010. Available at: http://www.pointcarbon.com/polo poly_fs/1.1545246!Carbon\%202010.pdf(Accessed $9^{\text {th }}$ Jan 2014).

Riley S (2007) Emission Rights Accounting: Accounting for Hot Air. Student Accountant ACCA(3): 48-51.

Romic V (2010) Development of emission rights and their accounting.Masters, University of Ljubljana, Slovenia.

Saunders, Lewis and Thorn hill (2007) Research Methods for Business Students. Harlow: Prentice Hall. 
Steenkamp N, Rahman A and Kashyap V (2011) Recognition, Measurement and Disclosure of Carbon Emission Allowances under the EU ETS-An Exploratory Study. Masters Thesis, CQ University, Australia.

Walter M (2006) Social Research Methods: An Australian Perspective. South Melbourne: Oxford University Press

Warwick P and Ng C (2012) The 'Cost' of Climate Change: How Carbon Emissions Allowances are Accounted for Amongst European Union Companies. Australian Accounting Review, 22(1): 54-67.

Veith S, Werner JR and Zimmerman J (2009) Competing Accounting Treatments for Emission Rights: A Capital Market Perspective. SSRN Journal. 